\title{
Long-Run Relationship between Exports and Imports of Pakistan
}

\author{
Ali Farhan Chaudhry ${ }^{1}$, Abdul Rauf Butt ${ }^{2} \&$ Muhammad Irfan Chani ${ }^{3}$ \\ ${ }^{1}$ Institute of Management Sciences, Lahore, Pakistan \\ ${ }^{2}$ Department of Economics Lahore Leads University, Lahore, Pakistan \\ ${ }^{3}$ COMSATS Institute of Information Technology, Vehari, Pakistan \\ Correspondence: Ali Farhan Chaudhry, Institute of Management Sciences, Lahore, 23 E-III Gulberg III, Lahore \\ 54660, Pakistan. Tel: 92-42-3575-1115-18. E-mail: afarhan_c@ hotmail.com
}

Received: December 26, 2016

doi:10.5539/ijef.v9n8p204
Accepted: July 18, 2017

Online Published: July 20, 2017

URL: https://doi.org/10.5539/ijef.v9n8p204

\begin{abstract}
The present study investigates dynamic relationship between exports and imports of Pakistan by using fiscal year data from1948-49 to 2012-13. ARDL co-integration technique has been employed to estimate the relationship and from empirical results, it is concluded that exports and imports are indeed co-integrated or in other words, long run equilibrium relationship does exist between exports and imports of Pakistan. It is further concluded that Pakistan is not violating its international budget constraints. VECM estimation also confirms that exports and imports are co-integrated and coefficient of error correction term indicates that in case of any departure from equilibrium exports adjust back at the speed of 17.147 percent of its last year disequilibrium value and it takes 5.832 years to fade away any impact caused by short term trade imbalances. Results obtained by Toda and Yamamoto (1995) test indicate that bi-directional causal relationship also exists between exports and imports of Pakistan. Findings of the current study has very important implications for policy makers to design such macroeconomic policies that can lead to establish long run equilibrium relationship between exports and imports adjusting short term trade deficit shocks to avoid violation of international budget constraints.
\end{abstract}

Keywords: ARDL Co-integration, exports and imports of Pakistan, VECM representation, causality

\section{Introduction}

Exports and imports play key role in economic growth of a country, especially, since introduction of global village concept. In such a closely netted world, it is difficult to find out the impact of macroeconomic policies on trade balance without contrived environment. One way to do is to investigate whether exports and imports of a country hold long run equilibrium relationship between them Bahmani-Oskooee and Rhee (1997). Investigation on long run relationship between exports and imports also shows whether a country is obeying international budget constraints or not.

According to Irandoust and Ericsson (2004), co-integrating relationship between exports and imports can explain that a country is not in violation of her international budget constraints and also that trade imbalances are short term phenomenon and macroeconomic policies have been effective to bring exports and imports into equilibrium in the long-run. They also concluded that absence of co-integration between exports and imports indicates major policy problems for the economy and the existence of productivity gap. So, investigation of long run relationship between exports and imports is equally important for both the developed and developing countries. Irandoust and Ericsson (2004) further found that the economy of Bangladesh is not violating its international budget constraints and its trade imbalances are a short-run phenomenon which are not sustainable in the long run. Therefore, the macroeconomic policies of Bangladesh have been effective in bringing total exports and imports into a long-run equilibrium.

Bahmani-Oskooee (1998), Wu and Zhang (1998), Tomšík (2001), Arize (2002), Baharumshah et al. (2003), Irandoust and Ericsson (2004), Choong et al. (2004), Kumar Narayan and Narayan (2005), Konya, Singh, and Pal (2008), and Jalil (2008) investigated long run relationship between exports and imports of some countries.

A few studies, besides this one, have found significant long run relationship between exports and imports of Pakistan, e.g., Kemal and Qadir (2005), Bader and Riazuddin (2006) and Naqvi and Morimune (2005), etc. However, a study conducted by Tang (2006) using the annual data from 1960 to 2000 of 27 member countries of 
Organization of Islamic Conference (OIC) found that exports and imports of Pakistan are not co-integrated. Afterwards, Mukhtar and Rasheed (2010) investigated a long run relationship between exports and imports of Pakistan by using quarterly data from 1972Q1 to 2006Q4 to allow sufficient observations required for co-integration estimation and found that exports and imports are indeed co-integrated.

The present empirical study attempts to investigate a long run relationship between exports and imports of Pakistan, for the first time, based on a longer time series data, i.e., from fiscal year 1948-49 to 2012-13, including all complete fiscal years since independence of Pakistan. The present study is expected to provide more reliable results as it is based on a longer time series data and is also expected to resolve the puzzle created by conflicting findings of Tang (2006), Hye and Siddiqui (2010) and etc. In addition, the present study also investigates co-integration along with vector error correction mechanism and Granger causality by using the longest available time series data of exports and imports of Pakistan.

The implication of the findings of the current study are very important for policy makers to design such macroeconomic policies that can lead to establish long run equilibrium relationship between exports and imports adjusting short term trade deficits shocks to avoid violations of international budget constraints.

The rest of the study is divided into four sections. Section II presents the review of literature. Section III describes data and devises the model and Section IV deals with empirical results and their analysis and in the last section, i.e., Section $\mathrm{V}$ conclusions are presented.

\section{Literature Review}

Bahmani-Oskooee and Rhee (1997) investigated a long run relationship between exports and imports of Korea by employing Johansen and Juselius (1990) co-integration approach on quarterly data for the period: 1963Q1 to 1991Q4. They found that exports and imports are co-integrated and have tendency to converge to long run equilibrium, which in turn shows that trade imbalances are not sustainable in the long run. A study carried out by Wu and Zhang (1998) investigated a long run relationship between exports and imports of the USA with Japan. They applied co-integration technique on a data set from 1966Q4 to 1994Q1. Wu and Zhang (1998) concluded from statistical results that after adjusting structural break exports and imports are co-integrated. They also concluded that trade deficit of USA with Japan is stationary.

A study by Arize (2002) looked into long run equilibrium relationship between exports and imports by employing Johansen (1995) methodology and used quarterly data of fifty countries for the period: 1973Q2 to 1998Q1. Statistical results lead to the conclusion that exports and imports do have a long run relationship in case of thirty-five countries and international budget constraints are sustainable for these specific thirty-five countries.

Baharumshah et al. (2003) found that exports and imports are co-integrated for Indonesia, Philippines, and Thailand by employing co-integration approach on annual data for the period: 1961 to 1999.The same study, by using the same estimation technique and data set concluded that exports and imports of Malaysia are not co-integrated. Contrast to this, another study conducted by Choong et al. (2004) found that exports and imports of Malaysia are co-integrated and converge to long run equilibrium and concluded that Malaysia is not violating international budget constraints. Similarly, Emmy et al. (2009) also found that exports and imports of Malaysia in forestry sector are co-integrated and a bi-directional causality does exist between them.

To investigate long run relationship between exports and imports of developed countries, such as France, Germany, Italy, Sweden, UK and USA Irandoust and Ericsson (2004) conducted an empirical study. They concluded from the statistical results that exports and imports of Germany, Sweden and USA are co-integrated but not in case of UK.

Tang (2006) examines long run relationship between exports and imports of 27 member countries of Organization of Islamic Conference (OIC) by employing co-integration technique devised by Gregory and Hansen (1996) which incorporates structural breaks in the data set. He concluded from the statistical results that exports and imports are co-integrated for only 9 out of 27 OIC countries not for rest of the countries including Pakistan. Another important study is carried out by Konya and Singh (2008) by employing Johansen's trace and the Saikkonen-Lütkepohl co-integration tests on trade data set: 1949-50 to 2004-2005 of India. Their statistical results lead to conclude that exports and imports of India are not co-integrated. This result implies that Indian macroeconomic decisions failed to establish long run relationship between exports and imports and also violate international budget constraints.

Jalil (2008) examines long run relationship between exports and imports of Bangladesh by employing residual based Engle Granger and VAR based Johansen co-integration tests. He used annual exports and imports data of Bangladesh from 1976 to 2006. Results indicate that long run relationship between exports and imports of 
Bangladesh does not exist. The statistical results further indicate that violation of international budget constraints is intact. Contrast to this, a study conducted by Uddin (2009) provides evidence that exports and imports of Bangladesh are co-integrated and also bi-directional Granger-causality between nominal exports and imports of Bangladesh does exist in the data set from 1972-73 to 2007-08. These findings lead to the conclusion that Bangladesh is not in violation of its international budget constraints and trade imbalances of Bangladesh are a short-run phenomenon, i.e., they do not sustain in the long run.

Dumitriu et al. (2009) investigated a long run equilibrium relationship between exports and imports of Romania by applying two-step residual based Engle and Granger (1987) and Johansen et al. (2000) cointegration approaches with trace test for structural breaks. They also employed a non-parametric Breitung test based on VAR structure to investigate causality between Romanian exports and imports. Dumitriu et al. (2009) used monthly data on exports and import of Romania from 2005M01 to 2009M04. Statistical results lead to conclude that exports and imports of Romania are not co-integrated and the gap between exports and imports is a violation of international budget constraints. They also found that bi-directional Granger causality does hold between exports and imports while imports have a bigger impact on exports.

Hye and Siddiqui (2010) investigated long run causality between exports and imports of Pakistan by using variance decomposition and rolling window bound testing approach. They used quarterly exports and imports data from 1985 to 2008. Their statistical results indicate that imports do not cause exports rather exports cause imports. They also conclude that Pakistan does violate international budget constraints.

A study by Mukhtar and Rasheed (2010) investigated a long run relationship between exports and imports of Pakistan by employing Johansen (1988) and Johansen and Juselius (1990) maximum likelihood co-integration approaches on annual exports and imports data from 1972 to 2006. Results lead to conclude that long run relationship does exist between exports and imports of Pakistan and results generated from VECM lead to conclude that bi-directional Granger causality also holds between exports and imports of Pakistan.

\section{Sources of Data and Methodology}

\subsection{Sources of Data}

To investigate long run relationship between exports and imports of Pakistan annual nominal data in Pak-rupee is used from fiscal year 1948-49 to 2012-13. The data is obtained from various issues of Statistics Bulletin of Pakistan published by Statistics Division of Pakistan.

\subsection{Methodology}

To investigate long run relationship between exports and imports of Pakistan the following linear regression model is specified.

$$
\text { Exportst }=\alpha+\beta \text { Importst }+\varepsilon_{t}
$$

Where, exports is the dependent variable and imports is the independent variable, $\alpha$ is intercept, $\beta$ is the regression coefficient, $\varepsilon$ is the error term and " $t$ " is time subscript.

The long run relationship between exports and imports of Pakistan is investigated by using ARDL test bound co-integration. Before investigating the long run relationship between exports and imports stationarity of time series data is checked by Augmented Dickey-Fuller (ADF) test which is presented below.

\subsubsection{Augmented Dickey-Fuller (ADF) Test}

To detect the presence of the unit root the Augmented Dickey-Fuller (ADF) test devised by Dickey and Fuller (1979) has been used. The general form of the ADF test is presented as:

$$
\begin{gathered}
\Delta X_{t}=\gamma X_{t-1}+\sum_{i=1}^{q} \phi_{i} \Delta X_{t-i}+e_{1 t} \\
\Delta X_{t}=\alpha+\gamma X_{t-1}+\sum_{i=1}^{q} \phi_{i} \Delta X_{t-i}+e_{2 t} \\
\Delta X_{t}=\alpha+\beta t+\gamma X_{t-1}+\sum_{i=1}^{q} \phi_{i} \Delta X_{t-i}+e_{3 t}
\end{gathered}
$$

$\mathrm{H}_{0}: \gamma=0$ (Unit root does exist and the time series is non-stationary).

$\mathrm{H}_{\mathrm{A}}: \gamma=0$ (Unit root does not exist and the time series is stationary).

The method of OLS has been used to estimate $\mathrm{Eq}(2)$ to $\mathrm{Eq}$ (4). The $\tau$ statistic of the estimated co-efficient of $\mathrm{X}_{\mathrm{t}-1}$ has been compared with its critical value computed by Dickey- Fuller (1979) and conclusion about stationarity/non-stationarity of the time-series has been made in a conventional way. 


\subsubsection{ARDL Co-Integration Test}

Long run relationship between exports and imports of Pakistan from model (1) is estimated by using Bound Testing Auto-Regressive Distributed Lag (ARDL) technique devised by Pesaran et al. (2001). Further, ARDL bound testing co-integration technique is applied once the order of the ARDL has been determined and then relationship is estimated by OLS. The statistic underlying this procedure is the familiar Wald or F-statistic in a generalized Dickey-Fuller type regression, which is used to test the significance of the lagged levels of the variables under consideration in a conditional unrestricted equilibrium error correction model devised by Pesaran et al. (2001) as:

$$
\begin{aligned}
& \Delta\left(\text { Exports }_{t}=v_{0}+\beta_{1}\left(\text { Exports }_{t-1}+\beta_{2}(\operatorname{Im} \text { ports })_{t-1}\right.\right. \\
& +\sum_{i=1}^{p-1} \theta_{\mathrm{i}} \Delta(\text { Exports })_{t-i}+\sum_{i=1}^{p-1} \eta_{\mathrm{i}} \Delta(\operatorname{Im} \text { ports })_{t-i}+\ldots \ldots \ldots \ldots . .
\end{aligned}
$$

After estimating model (5) by OLS, and then to estimate long run relationship between exports and imports of Pakistan restricted Wald test is carried out through F-statistic. Restrictions imposed while using Wald test on estimated long run coefficients as: $\mathrm{H}_{0:} \beta_{1}=\beta_{2}=0$, indicate that long run relationship does not exist between exports and imports of Pakistan. Against it, the alternative hypothesis $\mathrm{H}_{\mathrm{A}}: \beta_{1} \neq \beta_{2} \neq 0$, indicates that long run relationship does exist between exports and imports of Pakistan. Afterwards, comparison of observed F-statistic for Wald test on coefficient restrictions with critical value of F-statistic has been made. An observed F-Statistic below lower bound critical value indicates that null hypothesis cannot be rejected and in case the observed statistic is above upper bound critical value then it represents rejection of null hypothesis implying the variables are co-integrated while any value between lower and upper bounds indicates the test is inconclusive.

\subsubsection{Vector Error Correction Mechanism (VECM)}

Short run dynamic relationship between exports and imports of Pakistan is investigated by employing vector error correction mechanism (VECM) of ARDL. In addition, first differenced lagged values of exports and imports are regressed along with error correction term. The representation of VECM is given in equation (6) as:

$$
\Delta \text { Exports }_{t}=\alpha_{0}+\sum_{j=1}^{n} \beta_{1} \Delta \text { Exports }_{t-j}+\sum_{j=0}^{n} \beta_{1} \Delta \text { Imorts }_{t-j}+\eta \text { ECT }_{t-1}+e_{t}
$$

The significance of the coefficient of error correction term $\mathrm{ECT}_{\mathrm{t}-1}$ indicates the existence of short run relationship. Its estimated negative and positive values indicate the speed and convergence to or divergence from the long run equilibrium, respectively. A significant coefficient of error correction term with negative sign is considered as a further proof of the existence of stable long run relationship between variables (Banerjee et al., 1998).

\subsubsection{Granger Causality}

The Granger causality between exports and imports has been investigated by estimating Eq (7) and Eq (8).

$$
\begin{gathered}
\text { Export }_{t}=\alpha_{1}+\sum_{i=1}^{q} \beta_{i} \text { Exports }_{t-i}+\sum_{j=1}^{q} \gamma_{j} \text { Imports }_{t-j}+\varepsilon_{t} \\
\text { Imports }_{t}=\alpha_{1}+\sum_{i=1}^{q} \theta_{i} \text { Imports }_{t-i}+\sum_{j=1}^{q} \delta_{j} \text { Exports }_{t-j}+v_{t}
\end{gathered}
$$

To find the optimal lag length Schwarz Information Criteria (SIC) and Akaike Information Criteria (AI) have been used. Following Eq(7) Imports does Granger cause Exports if $H_{0}: \gamma_{j}=0$ (for all $\mathrm{j}=1,2,3, \ldots$.) is rejected which states that there is no causal relationship and $H_{A}$ : at least one $\gamma_{j} \neq 0$ (for all $\mathrm{j}=1,2,3, \ldots \ldots$ ) may be accepted stating that there is a causal relationship and for equation (8) Exports does Granger cause Imports if $H_{0}: \delta_{j}=0$ (for all $\mathrm{j}=1,2,3, \ldots$. ) is rejected which states that there is no causal relationship and $H_{A}$ : at least one $\delta_{j} \neq 0$ (for all $\mathrm{j}=1,2,3, \ldots \ldots$ ) alternative hypothesis is accepted which indicates that there is a causal relationship between variables.

\section{Results and Their Analyses}

Before estimating the long run equilibrium relationship between exports and imports of Pakistan the stationarity of time series is tested by employing Augmented Dickey-Fuller (ADF) unit root test and its results are given in Table 1 below. The results indicate that both imports and exports variables are not stationary at level, which implies that the null hypothesis of unit root at level cannot be rejected. However, both variables are stationary at the first difference that indicates the null hypothesis of unit root for exports and imports is rejected when tested for stationarity at the first difference of both variables. Thus the variables are integrated of order one I(1). 
Table 1. Results of Augmented Dickey-Fuller unit root test

\begin{tabular}{ccc}
\hline Variables & Intercept & Intercept and Trend \\
\hline Exports at level & 2.067043 & 0.644485 \\
& $(0.9999)$ & $(0.9995)$ \\
$\Delta$ (Exports) & -4.443253 & -6.512110 \\
& $(0.0006)$ & $(0.0000)$ \\
Imports at level & 6.891350 & 7.293347 \\
& $(1.0000)$ & $(1.0000)$ \\
$\Delta$ (Imports) & -3.637646 & -5.130939 \\
& $(0.0076)$ & $(0.0004)$ \\
\hline
\end{tabular}

Note. Numbers in parenteses represent p-value.

To investigate long run relationshiop between exports and imports of Pakistan ARDL co-integration technique has been applied and statistical results obtained from the technique are presetned in Table 2 below.

Table 2. Bound testing approach to Co-integration $\operatorname{ARDL}(1,0)$

\begin{tabular}{ccc}
\hline F-Statistic (Wald-Test) $\mathbf{4 2 . 4 5 5 0}$ & & \\
\hline Level of Significance & Lower Bound Value & Upper Bound Value \\
\hline $5 \%$ & 5.1470 & 6.0926 \\
$10 \%$ & 4.1490 & 4.9448 \\
W-statistic $=0.0000$ & & \\
\hline Level of Significance & Lower Bound Value & Upper Bound Value \\
\hline $5 \%$ & 10.2939 & 12.1853 \\
$10 \%$ & 8.2979 & 9.8895 \\
W-statistic $=0.0000$ & & \\
\hline$*$ The critical value bounds are computed by stochastic simulations using 20000 replications.
\end{tabular}

Note. * The critical value bounds are computed by stochastic simulations using 20000 replications.

The statistical results indicate that estimated F-statistic is above the upper bound at 5\% significance level. This means that the null hypothesis of no level effect is rejected and leads to the conclusion that exports and imports are co-integrated or in other words long run equilibrium relationship does exist between exports and imports of Pakistan.

On existence of co-integration, long run relationship between exports and imports is estimated and results are presented in Table 3 below.

Table 3. Estimated long run coefficients using the ARDL approach ARDL $(1,0)$

\begin{tabular}{|c|c|c|c|}
\hline \multicolumn{4}{|c|}{$\begin{array}{l}\text { Dependent variable: EXPORTS } \\
\text { Number of observations used for estimation: } 64 \text { (1949-50 to 2012-13) }\end{array}$} \\
\hline Regressor & Coefficient & Standard Error & t-Statistic [p-Value] \\
\hline Imports & 0.85196 & .20271 & $4.2029[.000]$ \\
\hline Constant & $5.19 \mathrm{E}+07$ & $4.51 \mathrm{E}+07$ & $1.1448[.257]$ \\
\hline
\end{tabular}

The statistical results presented in Table 3 above indicate that the estimated coefficient based on Schwarz Criterion of long run relationship between exports and imports is 0.85196 and is highly significant with a p-value of 0.000 . The value of the estimated coefficient indicates that one Pak-rupee increase in imports causes 0.85196 Pak-rupee rise in exports of Pakistan in the long run. This means that exports do not respond equally to imports, which happens to be one of the major causes of trade deficit in Pakistan. The estimated results of error correction mechanism (ECM) for ARDL $(1,0)$ model are presented in Table 4 below. 
Table 4. Error correction representation for the selected ARDL $(1,0)$ model

\begin{tabular}{|c|c|c|c|}
\hline \multicolumn{4}{|c|}{$\begin{array}{l}\text { Dependent variable is } \triangle \text { EXPORTS } \\
\text { Number of observations used for estimation: } 64 \text { (1949-50 to 2012-13) }\end{array}$} \\
\hline Regressor & Coefficient & Standard Error & T-Ratio[Prob] \\
\hline$\triangle \mathrm{IMPORTS}$ & .14609 & .045805 & $3.1893[.002]$ \\
\hline ECM(-1) & -0.17147 & .093322 & $-1.8374[.071]$ \\
\hline R-Squared & .61699 & R-Bar-Squared & .60443 \\
\hline S.E. of Regression & $5.19 \mathrm{E}+07$ & F-Stat. & 49.1323[.000] \\
\hline Mean of Dependent Variable & $3.71 \mathrm{E}+07$ & S.D. of Dependent Variable & $8.18 \mathrm{E}+07$ \\
\hline Residual Sum of Squares & $1.63 \mathrm{E}+17$ & Equation Log-likelihood & -1225.9 \\
\hline Akaike Info. Criterion & -1228.9 & Schwarz Bayesian Criterion & -1232.2 \\
\hline DW-statistic & 2.4195 & & \\
\hline
\end{tabular}

Note. ECM = Exports -0.85196 Imports $-(5.19 \mathrm{E}+07)$ Intercept.

Statistical results given in Table 4 above indicate that short run coefficient $(=0.14609)$ is significant with $p$-value of 0.002. It indicates that imports at first difference has positive impact on first difference of exports. It further indicates that one Pak-rupee increase in imports at first difference causes rise of 0.14609 Pak-rupee in first difference of exports in the short-run. Results also indicate that the estimated coefficient of $\operatorname{ECM}_{t-1}(=-0.17147)$ is significant having with $\mathrm{p}$ value of 0.071 with a sign consistent with a priori expectations that leads to the conclusion that exports and imports of Pakistan are cointegrated or in other words long run equilibrium relationship does exist between them. The speed of adjustment of exports, is measured by the absolute magnitude of estimated coefficient of error correction term $|0.17147|$ which in turn indicates that exports adjusts back 17.147 percent of its last year disequilibrium value. It further indicates that it takes 5.832 years to fade away disequilibrium represented by exports and caused by short-term shocks.

On existence of long run relationship between exports and imports of Pakistan, further investigation regarding causal relationship will provide information to formulate better policies. The direction of causality between exports and imports is investigated by employing Toda and Yamamoto (1995) technique. For causality estimation, optimal lag length of 2 as per Schwarz Information Criterion (SIC) and order of integration of one $\left(d_{\max }=1\right)$ are used and results are given below in Table 5.

Table 5. Causality between exports and imports of Pakistan

\begin{tabular}{cccc}
\hline & Null Hypotheses & F-Statistic & Prob. \\
\hline 1. & EXPORTS do not Granger Cause IMPORTS & 6.30122 & 0.0034 \\
2. & IMPORTS do not Granger Cause EXPORTS & 7.10627 & 0.0018 \\
\hline
\end{tabular}

The statistical results given in Table 5 above indicate that null hypothesis of exports do not Granger Cause imports cannot be accepted, as the value of F-statistic is 6.30122 with p-value of 0.0034 . Therefore, it can be concluded safely that causality from exports to imports does hold. The statistical results also indicate that the null hypothesis of imports do not Granger Cause exports cannot be accepted, as the value of F-statistic is 7.10627 with p-value of 0.0018 . This leads to the conclusion that causality from imports to exports also exists. From these results, it can be concluded that bi-directional causality does exist between exports and imports of Pakistan.

\section{Conclusions}

The present study investigates long run relationship between exports and imports of Pakistan by using annual time-series data from fiscal year 1948-49 to 2012-23. For estimation, ARDL cointegration technique is applied and from empirical results it is concluded that exports and imports of Pakistan are cointegrated or in other words long run equilibrium relationship does exist between them. The statistical results of the study also lead to the conclusion that Pakistan is not violating its budget constraint. These findings are align with Bahmani-Oskooee and Rhee (1997), Wu and Zhang (1998), Arize (2002), Baharumshah et al. (2003), Choong et al. (2004), Emmy et al. (2009), Irandoust and Ericsson (2004), Uddin (2009), and Mukhtar and Rasheed (2010) but differ from TangTang (2006), Konya and Singh (2008), Jalil (2008), Dumitriu et al. (2009), and Hye and Siddiqui (2010). Furthermore, the coefficient of long run relationship between exports and imports estimated by ARDL Model is 0.85196 that indicates that exports do not respond equally to imports, which happens to be one of the major 
causes of trade deficit in developing countries like Pakistan.

VECM estimation also confirms that exports and imports are co-integrated. Further, estimated coefficient of error correction term indicates that in case of any departure exports adjust back at the speed of 17.147 percent of its last year disequilibrium and it takes 5.832 years to fade away any impact. From the estimated results of Toda and Yamamoto (1995) causality test it is concluded that exports and imports of Pakistan have bi-directional causal relationship between them. This finding is align with Dumitriu et al. (2009), Uddin (2009), and Mukhtar and Rasheed (2010) but differ from Hye and Siddiqui (2010).

Findings of the current study has very important implications for policy makers to design macroeconomic policies that can lead to establish long run equilibrium relationship between exports and imports adjusting short term trade deficit shocks to avoid violations of international budget constraints. To sustain long run equilibrium relationship between exports and imports, any taxation on imports must be analyzed carefully before its implementation because it is reflected as taxes on exports evident by relative prices.

\section{References}

Arize A. C. (2002). Imports and exports in 50 countries: Tests of cointegration and structural breaks. International Review of Economics \& Finance, 11, 101-115. https://doi.org/10.1016/S1059-0560(01)00101-0

Bader, S., \& Riazuddin, R. (2006). Determining import intensity of exports for Pakistan State Bank of Pakistan.

Baharumshah, A. Z., Lau, E., \& Fountas, S. (2003) On the sustainability of current account deficits: Evidence from four ASEAN countries. Journal of Asian Economics, 14, 465-487. https://doi.org/10.1016/S1049-0078(03)00038-1

Bahmani-Oskooee, M. (1998) Cointegration approach to estimate the long-run trade elasticities in LDCs. International Economic Journal, 12, 89-96. https://doi.org/10.1080/10168739800080024

Bahmani-Oskooee, M., \& Rhee, H. J. (1997). Are imports and exports of Korea cointegrated? International Economic Journal, 11, 109-114. https://doi.org/10.1080/10168739700080007

Banerjee, A., Dolado, J., \& Mestre, R. (1998). Error-correction mechanism tests for cointegration in a single-equation framework. Journal of Time Series Analysis, 19, 267-283. https://doi.org/10.1111/1467-9892.00091

Choong, C. K., Soo, S. C., \& Yusop, Z. (2004). Are Malaysian exports and imports cointegrated? Sunway Academic Journal, 1, 29-38.

Dickey, D. A., \& Fuller, W. A. (1979). Distribution of the estimators for autoregressive time series with a unit root. Journal of the American Statistical Association, 74, 427-431. https://doi.org/10.1080/01621459.1979.10482531

Dumitriu, R., Stefanescu, R., \& Nistor, C. (2009). Cointegration and causality between Romanian exports and imports. Available at SSRN 2164553. https://doi.org/10.2139/ssrn.2164553

Emmy, F., Baharom, A., Radam, A., \& Illisriyani, I. (2009). Export and Import Cointegration in Forestry Domain: The Case of Malaysia.

Engle, R. F., \& Granger, C. W. (1987). Co-integration and error correction: representation, estimation, and testing. Econometrica: Journal of the Econometric Society, 251-276. https://doi.org/10.2307/1913236

Gregory, A. W., \& Hansen, B. E. (1996). Residual-based tests for cointegration in models with regime shifts. Journal of Econometrics, 70, 99-126. https://doi.org/10.1016/0304-4076(69)41685-7

Hye, Q. M. A., \& Siddiqui, M. M. (2010). Are imports and exports cointegrated in Pakistan? A rolling window bound testing approach. World Applied Sciences Journal, 9, 708-711.

Irandoust, M., \& Ericsson, J. (2004). Are imports and exports cointegrated? An international comparison. Metroeconomica, 55, 49-64. https://doi.org/10.1111/j.0026-1386.2004.00182.x

Jalil, M. (2008). Are Exports and Imports of Bangladesh Cointegrated? Available at SSRN 1313763.

Johansen, S. (1988). Statistical analysis of cointegration vectors. Journal of Economic Dynamics and Control, 12, 231-254. https://doi.org/10.1016/0165-1889(88)90041-3

Johansen, S. (1995). Likelihood-based inference in cointegrated vector autoregressive models. OUP Catalogue. https://doi.org/10.1093/0198774508.001.0001 
Johansen, S., \& Juselius, K. (1990). Maximum likelihood estimation and inference on cointegration with applications to the demand for money. Oxford Bulletin of Economics and statistics, 52, 169-210. https://doi.org/10.1111/j.1468-0084.1990.mp52002003.x

Johansen, S., Mosconi, R., \& Nielsen, B. (2000). Cointegration analysis in the presence of structural breaks in the deterministic trend. The Econometrics Journal, 3, 216-249. https://doi.org/10.1111/1368-423X.00047

Kemal, M. A., \& Qadir, U. (2005). Real exchange rate, exports, and imports movements: A trivariate analysis. The Pakistan Development Review, 177-195.

Konya, L., \& Singh, J. P. (2008) Are Indian exports and imports cointegrated? Applied Econometrics and International Development, 8, 177-186.

Kumar, N. P., \& Narayan, S. (2005). Are exports and imports cointegrated? Evidence from 22 least developed countries. Applied Economics Letters, 12, 375-378. https://doi.org/10.1080/13504850500067774

Mukhtar, T., \& Rasheed, S. (2010). Testing long run relationship between exports and imports: Evidence from Pakistan. Journal of Economic Cooperation and Development, 31, 41-58.

Naqvi, K., \& Morimune, K. (2005). An empirical analysis of the sustainability of trade deficits. Interfaces for Advanced Economic Analysis, June, 71-80.

Pesaran, M. H., Shin, Y., \& Smith, R. J. (2001). Bounds testing approaches to the analysis of level relationships. Journal of Applied Econometrics, 16, 289-326. https://doi.org/10.1002/jae.616

Tang, T. C. (2006). Are imports and exports in the OIC member countries cointegrated? A reexamination. International Journal of Economics, Management and Accounting, 14.

Toda, H. Y., \& Yamamoto, T. (1995). Statistical inference in vector autoregressions with possibly integrated processes. Journal of Econometrics, 66, 225-250. https://doi.org/10.1016/0304-4076(94)01616-8

Tomšík, V. (2001). Cointegration analysis of foreign trade in the Czech Republic, 1993-98. Czech Journal of Economics and Finance (Finance a uver), 51, 417-429.

Uddin, J. (2009). Time Series Behavior of Imports and Exports of Bangladesh: Evidence from Cointegration Analysis and Error Correction Model. International Journal of Economics and Finance, 1, 156. https://doi.org/10.5539/ijef.v1n2p156

Wu, Y., \& Zhang, J. (1998). Are the US exports to and imports from Japan cointegrated? Journal of Economic Integration, 626-643.

\section{Copyrights}

Copyright for this article is retained by the author(s), with first publication rights granted to the journal.

This is an open-access article distributed under the terms and conditions of the Creative Commons Attribution license (http://creativecommons.org/licenses/by/4.0/). 